\title{
The effect of PDT on $\mathrm{H}$. influenzae biofilm in vivo
}

\author{
Chung-Ku Rhee*, So-Young Chang, Phil-Sang Chung, Jae-Yun Jung, Jin-chul Ahn, Myung-Whan Suh \\ From 2nd Scientific Meeting of the Head and Neck Optical Diagnostics Society \\ San Francisco, CA, USA. 23-24 January 2010
}

\section{Introduction}

Biofilm formation has been demonstrated for many mucosal pathogens such as Haemophilus influenzae. The presence of mucosal biofilms with chronic otitis media with effusion (COME) suggests that bacteria do not clear by antibiotics.

\section{Aim}

To test the effect of photodynamic therapy (PDT) on $\mathrm{H}$. influenzae induced biofilm in vivo.

\section{Methods}

Sixteen bullae of 8 gerbils were injected with $200 \mu \mathrm{l}$ $(107 \mathrm{CFU} / \mathrm{ml})$ of $\mathrm{H}$. influenza and formation of biofilms in the bullae was obtained by 5 days. The bullae were divided into control, laser, photofrin, and PDT groups. The control group received no treatment. For laser group, $120 \mathrm{~J} / \mathrm{cm} 2(100 \mathrm{mw} \times 20 \mathrm{~min})$ of $632 \mathrm{~nm} \mathrm{LD}$ laser was irradiated into the bullae by a fiber inserted directly into the bullae. For photofrin group, photofrin $40 \mu \mathrm{l}(1 \mathrm{mg} / \mathrm{ml})$ were injected into the bullae. For PDT group, photofrin same as in photofrin group was injected into the bullae and LD laser was irradiated into the bullae same way as in laser group. The mucosal tissues in bullae were examined by $\mathrm{H} / \mathrm{E}$ staining, and SEM.

\section{Results}

The control, laser, and photofrin groups have shown well formed biofilm. Two third of the PDT group bullae have shown well resolved biofilm while $1 / 3$ of the bullae have shown incompletely resolved biofilms.

\section{Conclusion}

The results of this study demonstrated that PDT appears to be effective to treat experimental $\mathrm{H}$. influenzae induced biofilms in vivo. Further trial in different dose combinations of photosensitizer and laser needs to be tried for better results in PDT group.

Dankook University Hospital, Republic of Korea

\section{Clinical implication}

PDT may be an alternative to antiobiotic treatment on otitis media with biofilm formation.

Published: 29 October 2010

doi:10.1186/1758-3284-2-S1-O28

Cite this article as: Rhee et al:: The effect of PDT on $\mathrm{H}$. influenzae

biofilm in vivo. Head \& Neck Oncology 2010 2(Suppl 1):O28.
Submit your next manuscript to BioMed Central and take full advantage of:

- Convenient online submission

- Thorough peer review

- No space constraints or color figure charges

- Immediate publication on acceptance

- Inclusion in PubMed, CAS, Scopus and Google Scholar

- Research which is freely available for redistribution

Submit your manuscript at www.biomedcentral.com/submit
C Biomed Central 